\title{
JÜRGEN HABERMAS AND THE DEMOCRATIZATION OF WORLD POLITICS
}

\begin{abstract}
André Saramago
avsaramago@gmail.com

Invited Assistant Professor of International Relations at the University of Coimbra and the University Beira Interior (Portugal). He is also an Online Teaching and Research Assistant with DiploFoundation, University of Malta and an Associate Researcher with the Orient Institute. He holds a PhD in International Politics from Aberystwyth University. His areas of expertise include International Relations Theory, with a focus on Critical International Theory, Historical Sociology and East Asia studies. Amongst his recent published work, he is the editor of Climate Change, Moral Panics and Civilization, authored by Amanda Rohloff and published by Routledge, and of 'Singapore's use of education as a soft power tool in Arctic cooperation', co-authored with Danita Burke and published in the Asian Survey.
\end{abstract}

\section{Abstract}

This article consists of a review of Jürgen Habermas's discussions of the dilemma posed by human global interdependence to the possibility of democratic politics. According to Habermas, since the Second World War, and in a process that has become only more pervasive since the end of the Cold War, human societies have been brought into increasingly tighter and more complex political, social and economic networks of interdependence that have ultimately undermined the capacity of state-based democratic publics to have some degree of influence over their conditions of existence. From a critical international theory perspective, Habermas's argument highlights the fundamental contemporary challenge faced by the social sciences in general, and International Relations (IR) in particular. From that perspective, the fundamental task of IR is not only to explain world politics, but also to orientate social and political practice towards an expansion of democratic control over them. The purpose of this article is to show how Habermas's work makes a fundamental contribution to improve that critical orientating role of IR. The article connects Habermas's more recent political writings on the European Union (EU) and the United Nations (UN) with his earlier work on the development of a theory of social evolution. In doing so, it shows how Habermas's work can constitute the basis for an approach to the study of world politics that both understands how the present dilemma between global complexity and democracy came to be the defining feature of the present stage of human development, and that discloses the immanent potential gathered by modernity for a radical expansion of democratic politics to the level of world politics.

\section{Keywords}

International Relations; Critical international theory; Democracy; Power; Capitalism; European Union

How to cite this article

Saramago, André (2019). "Jürgen Habermas and the Democratization of World Politics". JANUS.NET e-journal of International Relations, Vol. 10, N.0 1, May-October 2019. Consulted [online] on the date of the last visit, https://doi.org/10.26619/1647-7251.10.1.2

Article received on October 15, 2018 and accepted for publication on February 26,2019

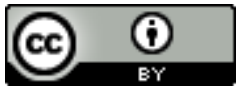




\title{
JÜRGEN HABERMAS AND THE DEMOCRATIZATION OF WORLD POLITICS
}

\author{
André Saramago ${ }^{1}$
}

\section{Introduction}

Throughout his vast career, Jürgen Habermas has been engaged in the development of a theory of social evolution that captures the dynamics of human historical development. In this context, Habermas came to characterise the history of the species as a long-term collective learning process in two interrelated fields; that of moral-practical knowledge and that of technical-instrumental knowledge (Habermas, 1987). While the former refers to learning at the level of collective norms that regulate social life, the latter refers predominantly to learning in the areas necessary to the material reproduction of social life, namely the control of non-human nature through productive activities. Habermas's argument is that, throughout history, different stages of development of moral-practical knowledge have been embodied in human societies' social norms and background shared moral understandings (what Habermas refers to as the 'lifeworld'), while different stages of technical-instrumental knowledge have been embodied in the economy and related spheres, such as bureaucratic and technical administrations (what Habermas refers to as the 'system'). Habermas's argument is that as human societies develop and become more complex, there is a rising tension between lifeworld and system. If, on the one hand, moral-practical learning creates the possibility to exercise greater democratic control over social life, on the other hand, social complexity creates pressures towards greater systemic autonomy, with bureaucratic and economic social sectors assuming dynamics of their own that escape democratic politics (Habermas, 1987).

In the last 20 years, Habermas $(1996 ; 2001 ; 2012)$ came to argue that modernity faces a fundamental 'systemic problem' that, with the global interweaving and interdependence of humanity brought about by globalization processes, now encompasses the whole world. A core feature of this problem is how, with the integration of national economies in a global capitalist market, and especially with the radical liberalization of financial markets since the end of the gold standard in 1971, there has been a dramatic increase in the autonomy of systemic contexts in relation to democratic publics that have remained state-bound (Habermas, 2001). This has undermined the balance between democracy and systemic autonomy that had been achieved within welfare states since the end of the Second World War. It is also the source of the contemporary resurgence of ethno-nationalist movements calling for a reinforcement of state sovereignty as a

1 I would like to thank Professor Andrew Linklater and Dr. Kamila Stullerova for comments on earlier drafts of this article. I would also like to thank the editorial board of JANUS.NET and the two anonymous reviewers whose comments greatly improved the quality of the article. 
supposed solution to the unplanned harmful social consequences of a global capitalist system that is out of control (Haro, 2017). However, to Habermas, a return to the state is an illusory escape from the problem. Rather, his argument is that it is necessary to develop a new 'principle of organisation' for world politics; one capable of expanding social adaptive capacity to the developmental challenges posed by growing global interdependence (Habermas, 2012).

In this context, Habermas has been mainly concerned with identifying the cognitive potential, available in modern worldviews and consciousness structures, for the development of such a principle of world political organisation that changes the prevalent balance between state-based democratic constituencies and global autonomous systems. In particular, Habermas is interested in understanding how the process of democratisation of social life, already initiated at the level of welfare democratic states, can be extended to world politics in a manner that reinforces human collective and conscious control over the systemic character of inter-state relations and the global capitalist economy.

Habermas's arguments in this regard are analysed in the following four sections. First, the article addresses Habermas's observations on how human global interweaving undermines the degree of democratic control that citizens of democratic welfare states are capable of exercising over their conditions of existence. Second, it considers Habermas's argument that a reconstruction of Kant's project for perpetual peace is required as an orientating framework regarding how the global web of humanity can be organised in a manner that guarantees a greater degree of collective and conscious control over its future development. Third, it analyses the connection between this argument and Habermas's more recent writings on the European Union, and on the decoupling between democracy and state power that can occur in its context. And fourth, the article addresses how Habermas's analysis of the EU informs his boulder proposal for a reform of the United Nations and associated radical democratization of world politics.

\section{Global interdependence and democracy}

Since 1971, with the end of the gold standard and subsequent radical liberalization of financial markets, the systemic dynamics of capitalism were unleashed from the boundary conditions established by national democratic publics and became capable of developing out of their own accord in conditions of greater autonomy. The capacity to freely move capital across the webs of the world economy meant that, increasingly, important areas of society were submitted to relations on the basis of money as the main means of social integration (Habermas, 2001: 78). This permitted multinational companies to withhold investment in certain states or social areas, blocking the access to important sources of revenue through taxation, unless states underwent reforms to make their internal conditions more adequate to the needs and interests of capitalist corporations. States have thus become increasingly compelled to compete with each other in making themselves more attractive to global business interests, namely, through the privatisation of areas such as health and education, the reduction of workers' salaries and benefits, the extension of working hours, and a combination of increased taxes for citizens with a reduction of corporate taxes (Habermas, 2001: 79).

Under these conditions, welfare states' social security systems, designed to alleviate the negative effects of capitalist development, became overburdened with rising 
unemployment and a shorter taxation basis. Increasingly, then, welfare states became a channel for the systematisation of national lifeworlds by global systemic imperatives and lost the capacity to guarantee democratic control over capitalist dynamics. Accompanying the growing intricacy of global economic networks, there also emerged unplanned chains of interlocking political decisions and outcomes that, when combined with the way that cultural and political identities are reshaped and rekindled by such processes, have made many local and regional sub-state actors question the legitimacy of the nation-state as a representative and accountable centre of power (Habermas, 1973; Habermas, 2006; Held, 1995: 136). The process of globalisation has thus 'enmeshed' nation-states in the dependencies of an increasingly interconnected world society whose systemic contexts 'effortlessly bypass territorial boundaries' (Habermas, 2006: 175; see also: Walker, 1988).

One of the answers to this situation has been the hegemonic behaviour exhibited by the United States (US) in the last two decades. Recent attempts by the superpower to use its military, technological and economic superiority to create a global order compatible with its 'religiously coloured notions of good and evil' constitute an expression of the historical possibility for the emergence of an 'imperial answer' to the challenge of regulating global interdependence (Habermas, 2006: 149). However, according to Habermas, the most likely outcome of the continued pursuit of such a strategy, given the inevitable resistance on the part of other great powers, such as Russia and China, is the emergence of a 'Schmittian' world order, characterized by the 'alarming prospect of competition among hemispheres' (Habermas, 2006: 148). Such a global order would, in effect, undermine the possibility of collective control over the process of globalisation, as the unplanned dynamics arising out of great power competition would push people and states into patterns of interaction not intended by any of them, and with potentially harmful implications for all the participants.

Instead, Habermas (2012) proposes an alternative 'principle of organisation' for world politics in the form of an extension, to the level of international society, of the long-term process of democratisation of social life that has hitherto been confined to the intra-state level. The democratic-legal taming of state power that has been occurring within welfare states needs to be carried further, in the form of a democratisation of the international system of states, that pacifies relations between states and controls their anarchic competition for power. Furthermore, such pacification would create the conditions for the establishment of new supranational procedures and institutions, as well as new forms of solidarity between people, on the basis of which a higher degree of conscious and collective control might come to be exercised over the dynamics of the global economic system.

In this context, Kant's project for perpetual peace is suggested as the most compelling alternative to the hegemonic proposal. However, it is also found to be in need of 'reconstruction' in light of Habermas's own research into long-term processes of legal pacification of state power.

\section{The political constitution of world society}

Kant's project is built on the awareness of the internal connection between peace and freedom (Kant, 2015; Habermas, 2006: 175). Only under conditions of international peace can human beings exercise a sufficient degree of control over inter-state relations 
that guarantees they are capable of freely self-determining their conditions of existence and not be dragged by the unplanned dynamics of inter-state competition and conflict. Both the pacification and the greater control of inter-state relations can be achieved, in Kant's view, through the establishment of a code of law regulating all possible dimensions of human interdependence (Kant, 1991). Respectively, civil law regulating relations between citizens within a state; international law regulating relations between states; and cosmopolitan law regulating relations between states and human beings in their quality of world citizens.

In Habermas's interpretation, (though there are others, see: Kleingeld, 2012; Mikalsen, 2011) Kant considers that such a code of law requires the constitution of a world federation of republican states with coercive powers to ensure its compliance. An understanding that Habermas contests by noticing how the actual historical development of international law since Kant's time leads to a different conclusion. Namely, that there is an important difference between the development of legal control over state power within states, and legal control over state power in the relations between states (Habermas, 2006: 122). The former implies a process in which an already existent monopoly over the means of legitimate violence comes to be circumscribed in its operation by civil laws that, concomitantly, depend on that same monopoly to guarantee their compliance. In the latter case, there is no supranational monopoly over the means of legitimate violence to ensure the application of international law. Rather, international law is developed and guaranteed on the basis of the expectation of self-restraint on the part of states. Hence, the development of international law 'runs counter' to the development of civil law, given that the main challenge at the level of international relations is how to make international law effective, and not how to tame and legitimize the power of an already existent monopoly over the means of legitimate violence (Habermas, 2006: 172). At the international level thus occurs what Habermas (2006: 134) refers to as a 'decoupling' of law and state power, which does not occur at the intrastate level.

If taken into account, this 'decoupling' shows that Kant's model of a 'democratic federal state writ large - the global state of nations or world republic - is the wrong one' (Habermas, 2006: 134). It is wrong not only because it understands the pacification of world politics as a reproduction of the process that already took place at the intra-state level, but also because it envisions that the monopoly over the means of legitimate violence and international law remain fused in a single institution, the world federation of states. Instead, an analysis of the actual historical development of international law reveals a decoupling between state power and law, which opens up the possibility for an alternative to Kant's world federation (see: Beardsworth, 2011: 32).

According to Habermas, this alternative is found in the possibility of a 'decentred world society', as a 'multilevel' global order that lacks the character of a state, but ensures collective democratic control over the dynamics of both the inter-state and the global economic systems (Habermas, 2006: 136). This multilevel world society implies not only the constitution of the three levels of law envisioned by Kant - respectively, the civil, the international and the cosmopolitan - but also the creation of three levels of decisionmaking. First, the supranational level of a world organization which is responsible for the clearly circumscribed tasks of securing peace and protecting human rights without, however assuming the state-like character of a world federation of states. Second, the transnational level in which great powers and continental unions of states address 
economic, social and ecological problems within the framework of permanent conferences. And third, the national level in which each state's lifeworld, expressed in their respective public spheres, can reacquire democratic control over national state power and the globally-connected national economy, given their integration in the multilevel world society (Habermas, 2006: 136). By stressing the plurality of legal orders in a politically constituted world society, Habermas effectively rejects the notion that law should form a unitary and hierarchical normative system, instead envisioning the coordination of legal orders to be guaranteed not by a vertical chain of authority, but rather by the performance of deliberative processes of consensualization of norms at different levels of decision-making.

Habermas (2006: 136) notes that, at the present historical juncture, only 'natural great powers', such as the USA, Russia or China, have the necessary resources to operate at the transnational level and establish continental regimes regulating economic, social and environmental policies in their respective areas of the globe. Consequently, in order to further give shape to this politically constituted world society, states in the various 'world regions have to unite to form continental regimes on the model of the European Union' (Habermas, 2006: 136). With this proposal for the political constitution world society, Habermas intends to show that a 'world republic' is not the only institutional form that the Kantian project can assume, nor is it the most adequate orientating device for how to pursue the pacification and democratization of world politics, given the cognitive potential gathered by world historical development (Beardsworth, 2011: 32)

The next two sections address in greater detail Habermas's reflections on the transnational and the supranational levels of his envisioned multilevel world society by focusing, first, on his discussion of the European Union and, afterwards, on his proposals for the reform of the United Nations.

\section{The European model}

Habermas's most elaborate proposal for the political constitution of world society is found in the compilation of texts entitled The Crisis of the European Union: A Response (2012). There, he argues that, under conditions of global interdependence, human beings can only attain a greater degree of democratic control over the global systemic dynamics that threaten them with environmental, economic and social disruption via the constitution of continental unions of states responsible for the regulation and coordination of policies in their respective areas of the globe.

The European Union (EU) is the longest surviving effort at extending the pacification of social life initiated within states to the international level. This effort has been developed in order to not only pacify the inter-state relations of a continent 'drenched in blood' but also to develop decision-making and steering capacities that enable European states to collectively exercise a greater degree of control over the dynamics of the international and economic systems that affect the continent as a whole and ignore state borders (Habermas, 2012: 28). An essential aspect of this process has been the development of European law regulating state behaviour without, however, the constitution of a European monopoly over the means of legitimate violence. The innovations coming into being in the EU can thus, in time, serve as a reference for other, less integrated, regional institutions (Habermas, 2001). In particular, the fact that European law is obeyed and has its own constituency independently of domestic law and state power sets a 
'precedent' for regional and global politics, effectively posing a new relation between law and power. This new relation is argued to provide a new 'model' for political organisation at the regional and global levels (Habermas, 2012, see also: Beardsworth, 2001: 98).

However, Habermas also notes that the democratization process in the context of the EU is far from finished. One of the main challenges is the fact that European economic integration has not been matched by the creation of democratic political institutions capable of regulating the common market. The EU's continued reliance on economic interdependence driven by business interests as the main integrative and pacifying force on the continent is 'no longer acceptable' without a concomitant effort to match the logic of market efficiency with the democratization of European political institutions (Habermas, 2012, Verovšek, 2012: 369). Decision-making processes at the level of the EU thus continue to be predominantly shaped by relations of power between states that escape the influence of national public spheres, while producing decisions that have a profound effect on the conditions of existence of the populations of each state. Hence, European law, while enabling the self-regulation of the European system of states, frequently lacks legitimacy in the eyes of European citizens given how it is not constituted by deliberative processes of consensualization between all those who stand to be affected by it (see: Linklater, 2007; Fraser, 2007). The present character of the EU is thus better described as form of 'executive federalism', in which the European Council, composed of representatives of each state, enacts measures that are implemented at the national level through governmental majorities that disempower national parliaments and escape the control of deliberative national publics (Habermas, 2012: 28). As such, national governments and bureaucratic administrations can use European institutions to escape the regulation of national public spheres and recover a degree of systemic autonomy from the normative constraints of national lifeworlds.

Habermas thus sees the EU as a highly contradictory social formation. On the one hand, it has contributed to the pacification of European inter-state relations and to the development of European institutions with the capacity to extend legal and democratic control over systemic forces that have bypassed national boundaries. But, on the other hand, these same institutions reinforce the autonomy of state power vis-à-vis national lifeworlds and diminish the level of collective democratic control that people are capable of exercising over their lives, becoming a 'kind of post-democratic, bureaucratic rule' (Habermas, 2012: 52). The EU is a 'paradox' to the extent that it shows marked tendencies for a deepening of its democratic deficit while also gathering the potential to serve as a vehicle for the extension of democratic governance beyond the nation-state and thus for the development of democratic boundaries on the 'socially corrosive' impacts of globalisation (Habermas, 2001; Grewal, 2001).

The EU stands at a crossroads in Habermas's assessment. On the one hand, it faces the danger of a deepening of its democratic deficit by becoming a conveyer belt for the transformation of national lifeworlds according to the systemic pressures of state bureaucracies and capitalist interests. On the other hand, the historical development of European institutions and the legal pacification of the continent constitutes a 'novel' event in world politics that gathers the immanent potential for extending democratic decisionmaking to the transnational level of world society. Such an extension would permit the constitution of a European 'transnational democracy' that further approximates an 'ideal communication community' (Habermas, 2012: 52). 
The main difficulty facing the democratization of the EU, Habermas observes, is that, except for the European Parliament, democratic institutions of decision-making continue tied to the state level. In this context, some have argued that the democratization of the EU is impossible given the absence of a common 'demos' beyond European nation-states, a collective European identity that creates bonds of solidarity between European citizens and makes them a single constitutional subject (Dahl, 1999). The 'no demos' thesis can, however, be contested in light of Habermas's theory of social evolution that notes that while the 'nation' has served as the basis for political community at the state level, it has done so only to the extent that it was the historical solution to the tension inherent in the identity of modern citizens. A tension between their universal moral character, which is 'better suited to world citizens', and the reality of the fragmentation of world politics between different nation-states (Habermas, 1979: 115). As such, inherent in the moral orientations of modernity is already present the cognitive potential to overcome the 'nation' as the main principle of organisation for political communities (Habermas, 2006: 76).

In modern, universalistic worldviews and consciousness structures lies the potential for the validity and legitimacy of social norms to derive less from being grounded in ethnonationalist identities than in universal principles that have been constituted via deliberative processes of consensualization involving all those who stand to be affected by them. This deliberative character of the validity and legitimacy of law implies its decoupling from the background of shared national traditions. Decision-making processes concerning common problems can thus be informed by 'principles of justice' rather than in terms of the 'fate of the nation', given how people's 'emotional fixation' can move from the ethno-national community to the deliberatively constituted law (Habermas, 2006: 77-78). Increasingly, 'civic solidarity' can be defined not by belonging to a common nation-state, but instead by a common allegiance to deliberatively achieved constitutional principles embodied in law. From that perspective, it becomes possible to conceive of an 'enlargement' of civic solidarity and of the boundaries of political community to encompass non-nationals and outsiders as rightful members of a transnational dialogic community of co-legislators who are bound by their affectability by common norms, rather than by shared cultural orientations or political aspirations (Linklater, 1998: 85; 2017). Habermas calls this transnational civic solidarity 'constitutional patriotism' (Habermas, 2006: 53; Habermas, 2006b: 118).

Constitutional patriotism expresses a possible new principle of organisation for welfare states and world politics that permits the expansion of civic solidarity beyond the frontiers of the 'nation'. It points to the possible emergence of a European-wide civic solidarity that binds together in a 'post-national constellation' people from different states through a shared allegiance to the principles of European law, which they collectively recognise as legitimate and valid if these principles derive from deliberative processes of decisionmaking involving all those who stand to be affected by them. The cognitive potential for the development of European transnational democracy is thus already present in the modern worldviews and consciousness structures of the citizens of modern European welfare states.

In fact, according the Habermas, the partial actualization of this cognitive potential of modern world views can already be observed in the growing decoupling of European law from state power. The Lisbon treaty is an expression of this process when, in the absence of a European monopoly over the means of legitimate violence, derives the legitimacy of 
European law from constitutional principles that have been constituted by the EU's 'dual constitutional subject', which is defined as the national peoples (represented by their states) and the citizens of the European Union (Habermas, 2012: 37). In Habermas's view, the Lisbon treaty thus confirms de jure what the EU has historically denied de facto; i.e. that the legitimacy of European law can only be secured if it derives from democratic deliberative processes of decision-making involving both the citizens and the memberstates of the Union. Consequently, the present decoupling of European law from state power on which the EU is structured, as well as the validity of European law, can only be maintained if the Union actualises the ideal of the political constitutionalization of world society at the transnational level and makes the 'dual constitutional subject' of the Union an institutional reality (see: McCormick, 2007).

The institutional apparatus for the actualization of the 'dual constitutional subject' is already in place, in the form of European citizenship and institutions such as the European Parliament and the European Council. What is required is that these institutions embody the cognitive potential gathered in modern worldviews and consciousness structures by establishing a European-wide democratic 'two-track' decision-making process. One that enables individuals, both in their quality of European citizens, and of citizens of their respective national states, to participate - respectively in the Parliament and the Council - in the constitution of European law (Habermas, 2012: 28). This scenario implies that the 'same persons' will embody these two roles in 'personal union' and adopt 'different justice perspectives' depending on which of the two decision-making tracks is involved. What counts as a 'public' interest in deliberative processes that they undertake as citizens of a state, changes into a 'particularistic' interest in deliberative processes that they undertake as European citizens. (Habermas, 2012: 37). This tension arises from the dual character of the decision-making process and has important consequences for the democratic character of the European Union.

On the one hand, it ensures that European law actually possesses democratic validity and can secure its compelling power to regulate inter-state relations, even in the absence of a European monopoly over the means of legitimate violence. Furthermore, it also extends the level of democratic control that European citizens are capable of exercising over the systemic contexts affecting the European continent - be it those of inter-state relations or those of the capitalist market. On the other hand, the fact that the dual constitutional subject of the EU is composed not only by European citizens, but also by the states of the Union, means that European law cannot be superimposed on national constitutional laws. Each state is capable of safeguarding its own internal legal and normative framework, by ensuring that European law must satisfy the standards of civil liberties that have already been historically achieved at the state level. Hence, European law embodies both the 'universal' orientations of European citizens and protects the 'difference' of the several cultural biotypes of each one of the national peoples of the Union (Habermas, 2012: 40).

The transformation of the European Union into a transnational democratic association of states and citizens would contribute to the actualisation of the new principle of organisation of world politics which is immanent in modern worldviews and consciousness structures. It would be a 'further step' in the political constitution of world society and in the democratization of world politics by permitting deliberative publics to acquire a greater degree of collective and conscious control over the systemic dynamics of inter- 
state and global economic relations, which have escaped their control within welfare states (Linklater, 1998: 167; Linklater, 2011).

However, Habermas is well-aware that any such developments in the European Union are necessarily intertwined with wider dynamics of the international system and global capitalism and that the democratization of the transnational EU level can only be successful if framed in the wider democratization of world politics. The next section thus turns to how Habermas's reflections on the EU are complemented by his work on the potential for the political constitutionalization of the supranational level of human interdependence. Namely, it considers his proposal for a reform of the United Nations as a condition for the expansion of democratic control over the global inter-state and capitalist systems that presently undermine human beings' capacity to self-determine their conditions of existence.

\section{The cosmopolitan condition}

The goal of expanding democratic legal control over systemic contexts beyond national borders derives its impetus from a 'paralysing constellation' in world politics. The globalisation of human interdependence has 'exhausted' the capacity of states to answer to the problems posed by the global systemic forces of inter-state competition and capitalism that have developed beyond the control of even the most powerful states or unions of states (Habermas, 2012: 54). Hence, transnational efforts at democratic legal regulation, such as those of the European Union, must be complemented by the further democratization of world politics. Namely, via a reform of the United Nations that democratizes its role in the legal definition of the boundary conditions for the operation of inter-state relations and capitalist markets.

According to Habermas (2006: 137), the democratic reform of the UN demands a transition to a 'cosmopolitan condition' in world politics, characterized by the 'substitution' of international law by cosmopolitan law. Unlike current international law, cosmopolitan law would be the result of decision-making processes involving not only states, but also world citizens in their quality of constitutional subjects of the world organisation. The UN would thus have to institutionally embody the two innovations that Habermas sees as immanent in the transnational level of the EU. On the one hand, it would have to ensure the compliance of member states with cosmopolitan law even though the monopoly over the means of legitimate violence would remain at state level. On the other hand, it would have to institutionally embody a 'dual constitutional subject', composed of world citizens and national peoples; represented by their respective states, or by other representative entities, such as NGO's, in the case of sub-state or stateless peoples (Habermas, 2012: 54).

While the first of these two conditions can already be discerned in the institutional framework of the United Nations, the actualisation of the second element requires the attribution, to every single human being on the planet, of the status of world citizen, and the constitution, parallel with the General Assembly, of a 'world parliament' composed by their elected representatives (Habermas, 2012: 58; see parallels between Habermas's proposal for world citizenship and those made by Apel (2007) who, however, lacks Habermas' level of engagement with the institutional changes that might be required to actualize forms of world/cosmopolitan citizenship). The world parliament would not transform the United Nations into a world republic, but it would reinforce the democratic 
legitimacy of cosmopolitan law by making world citizens, alongside with states, one of its constitutional subjects. In other words, in the same manner of what would take place in an EU transformed into a transnational democracy, cosmopolitan law would not superimpose itself on national constitutional law or ethno-national conceptions of the good life. Member-states, as the second constitution-founding subjects, would be able to protect their internal orders from cosmopolitan law that did not meet their standards of civil liberties (Habermas, 2012: 58). Furthermore, since the world organisation is not a world federation of states and does not possess a supranational monopoly over the means of legitimate violence, it would have to rely on 'national monopolists' for the fulfilment of its tasks, including those envisioning the implementation of coercive measures in order to reinstate compliance with cosmopolitan law. The need for the world organisation to rely on member-states in this manner not only confirms the decoupling between law and state power that characterizes the political constitution of world society, but also ensures the protection of the autonomy of states through the maintenance of the monopoly over the means of legitimate violence at the state level (Habermas, 2012: 61). In this manner, the democratization of world politics envisaged by Habermas would effectively 'wed together' the Kantian ideal of equal membership of a universal kingdom of ends with the Marxian project of dismantling systems of domination and exclusion that undermine human autonomy by promoting new relations between universality and difference (Linklater, 1998).

Essential in this regard, according to Habermas, is that the world organisation restrict itself to the tasks of maintaining peace and protecting human rights, leaving decisionmaking processes related to economic, social or ecological problems to the transnational level of world society. The restriction of the UN to this narrow set of core functions derives from the argument that issues related to economic, social or ecological problems, while expressing a 'shared abstract interest' of all human beings, necessarily imply answers that relate to particular conceptions of the 'good life' (Habermas, 2012: 63). These are issues whose answers involve the self-affirmation of particular cultural and political identities and, as such, while admitting of consensualization between people who share common cultural characteristics as part of their collective history and belonging to a particular region of the globe, are not liable to truly universal answers arising from global processes of consensualization between world citizens. Consequently, these issues should be dealt with at the transnational level, where continental unions of states in the same cultural areas can potentially come closer to common agreements on preferable 'ways of life' (Habermas, 2012: 63). However, the same judgement does not apply to issues of world peace and human rights. In Habermas's (2012: 64) assessment, these issues express an a priori general interest shared by the world population, 'beyond all political-cultural divisions', in the avoidance of violence and in the expression of solidarity with 'everything that has a human face'. These issues have an inherently universal character, to the extent that shared human vulnerability to war and violence is a common feature of the species (see: Linklater, 2011). As such, their discussion is liable to produce truly universal answers, arrived at through global processes of consensualization of norms involving world citizens and all the states into which humankind is divided. The world organisation must thus restrict itself to those issues that admit of universally shared human interest.

According to Habermas, the universal, species-wide, character of the core functions of the UN also means that the world organisation has different legitimacy requirements than 
the transnational level of continental unions. Given that 'negative duties to refrain from unjustifiable human rights violations and wars of aggression are rooted in the core moral content of all the major world religions and in the cultures they have shaped', global civic solidarity amongst world citizens can be based on these shared convictions and does not require a deeper collective commitment to a common conception of the 'good life', as occurs at the transnational level (Habermas, 2012: 65). Consequently, the democratic assessment of the deliberative decision-making processes of the world parliament can be based only on the 'expression of the, in essence morally justified, "yes" or "no" to the supranational application of presumptively shared moral principles and norms' (Habermas, 2012: 65). So, while the legitimacy of law at the transnational European level demands not only a dual constitutional subject but also the permanent consideration of transnational issues in a European public sphere, the weaker legitimacy requirements of cosmopolitan law do not demand the formation of a permanent global public sphere. They simply require the thematic and temporally circumscribed constitution of a global public 'sparked intermittently by this or that major event without achieving structural permanence' (Habermas, 2012: 62).

\section{Conclusion}

Habermas's reflections on the possibility of democratization of world politics provide an important starting point to discuss how to deal with the erosion of the capacity of statebound democratic publics to control the social processes that bind them together at the global scale. In Habermas's assessment, the answer to this erosion demands a new principle of organisation for world politics. One whose actualization lies immanent in the cognitive potential that has been gathered in modern consciousness structures by the long-term process of human development. According to Habermas, the cognitive potential of modernity implies the possibility of a decoupling between democracy and state power, on the basis of which the political constitution of world society can occur in a manner that would re-establish the balance between democratic politics and the systemic imperatives of global capital and inter-state relations. Habermas's theory of social evolution thus provides a highly compelling approach to a critically-committed IR that seeks to fulfil its role as a means of orientation that is adequate to deal with the challenges posed by the complexity of human global interdependence. In other words, an IR that seeks to constitute itself as an orientating framework that can help people both acquire a better understanding of themselves and of their present historical context and identify what sort of international institutional innovations are required to actualize the immanent potential of modernity for a further expansion of human beings' capacity to self-determine their conditions of existence.

Habermas's proposals, however, constitute only a starting point for the development of such an IR. Further works needs to be done, especially in better connecting Habermas's philosophical-theoretical proposals with more concrete historical-sociological analyses of world politics. For example, it is debatable whether Habermas's restriction of the tasks of the world organization to those of the maintenance of peace and human rights - under the argument that these tasks, unlike those related to economic, social and ecological problems, are more universal and less bound with particular conceptions of the good life - is completely tenable. The historical record shows that matters such as the maintenance of peace and human rights are as politicized and caught up with particular 
conceptions of the good life as those related to economic, social and ecological problems. Sufficient evidence of this can be found in the numerous debates in the Security Council surrounding the legitimacy of international interventions in the name of the maintenance of peace or in recent debates about whether human rights, as currently conceived, are truly universal, or if their content is still expressive of a phase of predominance of Western powers in international society (see: Sun, 2016; Qi, 2005; Regilme, 2018). Furthermore, recent developments in world politics have seen international organizations at the transnational level, such as the European Union or the African Union, assuming, or with the intention of assuming, a greater role at the level of the maintenance of peace and security in their respective areas of the globe (see: Joshua and Olanrewaju, 2017; Nováki, 2018). And finally, it is highly debatable whether problems that arise with economic, social and ecological interdependence can be adequately dealt with purely at the level of transnational continental unions, or whether these issues, especially in the context of increasingly out-of-control capitalist globalization and global climate change processes, do not require also at least some degree of global coordination; a coordination that would necessarily have to take place at the level of Habermas's envisioned world organization.

As such, Habermas's critical approach to world politics needs to be further developed, namely through a deeper engagement with the historical-sociological study of world politics in order to disclose the actual existing immanent potentials for the development of the type of 'cosmopolitan vision' Habermas is seeking to nurture (see: Beck, 2006). Recent developments in critical international theory appear to be moving in this direction, either calling for the need for greater historical-sociological engagement (Schmide, 2018, Devetak, 2018), or seeking to develop it themselves (Linklater, 2016). It is up to contemporary and future scholars to complete this task and understand if, and how, Habermas's ethical vision for the future of world politics might be actualized.

\section{References}

Apel, Karl-Otto (2001). «Discourse Ethics, Democracy and International Law: Toward a Globalization of Practical Reason». The American Journal of Economics and Sociology (66:1): 49-70.

Beardsworh, Richard (2011). Cosmopolitanism and International Relations Theory. Cambridge: Polity Press.

Beck, Ulrich (2006). Cosmopolitan Vision. Cambridge: Polity Press.

Dahl, Robert (1999). «Can International Organisation be Democratic? A Sceptic's View». In Shapiro, Ian and Hacker-Cordon, Casiano (eds.) Democracy's Edges. Cambridge: Cambridge University Press, 19-36.

Devetak, Richard (2018). Critical International Theory: An Intellectual History. Oxford: Oxford University Press.

Fraser, Nancy (2007). «Transnationalising the Public Sphere: On the legitimacy and efficacy of public opinion in a post-Westphalian world». Theory, Culture and Society (24:4): 7-30.

Grewal, Shivdeep (2001). «The Paradox of Integration: Habermas and the Unfinished Project of European Union». Politics (21:2): 114-123. 


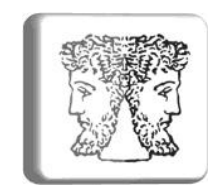

Habermas, Jürgen (1973). Legitimation Crisis. London: Heinemann.

Habermas, Jürgen (1979). «History and Evolution». Telos (39): 5-44.

Habermas, Jürgen (1987). The Theory of Communicative Action, vol. 2: Lifeworld and System - The Critique of Functionalist Reason. Cambridge: Polity Press.

Habermas, Jürgen (1996) Between Facts and Norms: Contributions to a Discourse Theory of Law and Democracy. Cambridge: Polity Press.

Habermas, Jürgen (2001). The Postnational Constellation. Cambridge: Polity Press.

Habermas, Jürgen (2006). The Divided West (Cambridge: Polity Press.

Habermas, Jürgen (2006b). Times of Transition. Cambridge: Cambridge University Press.

Habermas, Jürgen (2012). The Crisis of the European Union: A Response. Cambridge: Polity Press.

Haro, Fernando (2017). «The Decivilizing Effects of the Financial System». Human Figurations: Long-term perspectives on human development (6:2).

Held, David (1995). Democracy and the Global Order: From the Modern State to Cosmopolitan Governance. Cambridge: Polity Press.

Joshua, Segun and Olanrewaju, Faith (2017). «The AU's Progress and Achievements in the Realm of Peace and Security». India Quarterly: A Journal of International Affairs (73:4): 454-471.

Kant, Immanuel (1991). «Perpetual Peace: A Philosophical Sketch». In Hans Reiss (ed.) Kant: Political Writings. Cambridge: Cambridge University Press, 93-130.

Kant, Immanuel (2015). Critique of Practical Reason. Cambridge: Cambridge University Press.

Kleingeld, Pauline (2012). Kant and Cosmopolitanism: The Philosophical Ideal of WorldCitizenship. Cambridge: Cambridge University Press.

Linklater, Andrew (1998). The Transformation of Political Community: Ethical Foundations of the PostWestphalian Era. Cambridge: Polity Press.

Linklater, Andrew (2007). «Public Spheres and Civilising Processes». Theory, Culture and Society (24:4): 31-37.

Linklater, Andrew (2011). The Problem of Harm in World Politics: Theoretical investigations. Cambridge: Cambridge University Press.

Linklater, Andrew (2016). Violence and Civilization in the Western States-Systems. Cambridge: Cambridge University Press.

McCormick, John (2007). Weber, Habermas and the Transformation of the European State: Constitutional, Social and Supranational Democracy. Cambridge, Cambridge University Press.

Mikalsen, Kjartan. (2011). «In Defense of Kant's League of States». Law and Philosophy (30:3): 291-317.

Nováky, Niklas (2018). «The EU's Permanent Structured Cooperation in defence: Keeping the Sleeping Beauty from snoozing». European View (17:1): 97-104. 
Qi, Zhou (2005). «Conflicts over Human Rights between China and the US». Human Rights Quarterly (27:1): 105-124.

Regilme, Salvador (2018). «The Global Human Politics of Human Rights: From Human Rights to Human Dignity?». International Political Science Review (40:2): 279-290.

Schmide, David (2018). «The Poverty of Critical Theory in International Relations: Habermas, Linklater and the Failings of Cosmopolitan Theory». European Journal of International Relations (24:1): 198-220.

Sun, Pinghua (2016). «Chinese Discourse on Human Rights in Global Governance». The Chinese Journal of Global Governance (1:2): 192-213.

Verovšek, Peter. (2012). «Meeting Principles and Lifeworlds Halfway: Jürgen Habermas on the Future of Europe». Political Studies (60:2): 363-380.

Walker, Rob (1988). One World, Many Worlds: Struggles for a Just World Peace. London: Zed Books. 